\title{
Pre-lacteal feeding practices among newborn in urban slums of Lucknow city UP, India
}

\author{
Pratibha Gupta $^{1^{\star}}$, Vinod K. Srivastava ${ }^{2}$, Vishwajeet Kumar ${ }^{3}$, Jyoti Prakash Srivastava ${ }^{1}$ \\ ${ }^{1}$ Department of Community Medicine, Era’s Lucknow Medical College \& Hospital, Lucknow, India; \\ *Corresponding Author: pratibha_jayant@yahoo.co.in \\ ${ }^{2}$ Integral Institute of Medical Sciences, Integral University, Lucknow, India \\ ${ }^{3}$ KGMU-JHU Collaborative Projects, King George’s Medical University, Lucknow, India
}

Received 10 July 2012; revised 26 September 2012; accepted 16 October 2012

\begin{abstract}
Aim: To study the Practices of Pre-lacteal feeding among Newborns in Urban slums of Lucknow city. Setting and Design: A cross-sectional study in Urban slums of Lucknow city, UP. Methods and Material: A cross-sectional study in Urban slums of Lucknow city, UP included 524 women who had a live birth during last one year preceding data collection. A pre-desined and pretested questionnaire was used for data collection. Statistical Analysis Used: The data was tabulated on Microsoft Excel sheet and analyzed using the software SPSS $\mathbf{1 0 . 0}$ for Windows and Discrete data were analyzed using the chi-square test. Results: Study findings showed that Half (50.6\%) of the mothers had given pre-lacteal feedings to their newborn. Out of those who had given pre-lacteal feed, 55.1 percent had given mugli ghutti/griipe water and 49.4 percent had given boiled water as pre-lacteal feed Only mother's education ( $p<0.01)$, father's education ( $p$ $<0.001)$ and socioeconomic status $(p<0.05)$ were statistically associated with the practice of giving prelecteal feeding. Conclusion: It was concluded that maternal knowledge and awareness of correct feeding practices is essential for the normal growth, health and well being of the children. We therefore suggested that the primary focus of various nutrition related national programs in India for children should aim at imparting nutrition and health education to the mothers.
\end{abstract}

Keywords: Newborn; Prelacteal Feeding; Urban Slums

\section{INTRODUCTION}

Exclusive breastfeeding (EBF) is recommended as the optimum method of feeding for the first 6 months of life and semi-solid foods are to be introduced after 6 months while continuing breastfeeding to meet the physiological requirements of the infants [1].

Other studies from urban slums repeatedly documented that exclusive breastfeeding was practiced in only $30 \%$ $40 \%$ of infants, colostrum was discarded in up to $90 \%$, use of prelacteal feeds was almost universal, use of feeding bottles, animal milk, and commercial milk formulae was very common [2].

World Health Organization (WHO) and United Nations Children's Fund (UNICEF) recommend that all mothers should breastfeed their children exclusively for the first 6 months and thereafter they should continue to breastfeed for as long as the mother and child wish, and both appropriate and sufficient weaning food should be added after six months of life [3,4]. In order to achieve the millennium Development Goal of reduction of child mortality, infant breastfeeding has been identified as one of the major intervention areas both globally and nationally $[5,6]$.

Aim: The study had been conducted to assess the prelacteal feeding practices among newborns in an urban slums of Lucknow city and to determine the factors influencing it.

\section{MATERIAL AND METHODS}

\subsection{Study Population}

The present study was carried out among newborns in urban slums of Lucknow city. Lucknow city is a city of Nawabs, with a Population of about 40 lacs. Mixed population of Hindus and Muslims. Approximate Family size is about 5.6. reason for selecting for study is that I was studying in Lucknow and it was easy to carry out study in this area and also to aware the Mothers regarding Feeding Practices of New Borns.

The actual accessible population from which the sample was taken, was defined as "All those households hav- 
ing mothers who gave birth to a live born within the last one year".

\subsection{Study Design Cross-Sectional Study}

\subsubsection{Sampling}

Sample size was calculated on the basis of percent distribution of children who were fed colostrum. According to NFHS, UP (1998-1999) percentage of children who were fed colostrums was 25 percent. An absolute permissible error of 4 percent was taken to calculate the sample size. Considering a 10 percent of non response, the sample size came out to be 517 , however in the present study 524 children were covered.

\subsubsection{Sampling Technique}

There are eight Maternal and Child Health Centre (Bal Mahila Chikitsalaya) in Lucknow city. For sampling purpose at first stage, one maternity centre was selected randomly which was Aliganj, Maternal and Child Health Centre. This centre covers a total of 33 slums covering a population of about 40,000. Considering an average family size of 5.6 for the slums of Lucknow, there would be about 7142 households and 1100 children below one year of age. In order to cover desired sample size of 524 systematic random sampling was used and. Every second household was surveyed.

\subsubsection{Analysis and Interpretation of Data}

Pretested and predesigned questionnaire was used. Interview was taken from Mothers regarding pre lacteal feeding practices of Newborns.

The data was tabulated on Microsoft Excel sheet and analyzed using the software SPSS 10.0 for Windows. Discrete data was analyzed using Chi-square test. Binomial analysis was performed with prelacteal feeding practices as dependent variable and socio-demographic characteristics as independent variable.

\section{RESULTS}

A total of 524 families were surveyed. There were 29.4 percent Muslims and 70.6 percent Hindus families. Amongst Hindus 33.6 percent belonged to OBC, 26.3 percent belonged to SC/ST and 10.7 percent belonged to general caste. The majority (70\%) of the families were nuclear type. More than half (59.5\%) of the mothers were illiterate. About one fifth (21.2\%) of the mothers had education level up to junior/high school level. More than one third (45.8\%) of fathers were illiterate $(45.8 \%)$ and 27.8 percent had education level up to junior/high school level (Table 1).

Half $(50.6 \%)$ of the mothers had given pre-lacteal feedings to their newborn. Out of those who had given pre-lacteal feed, 55.1 percent had given mugli ghutti/ griipe water and 49.4 percent had given boiled water as pre-lacteal feed. About one third (34.7\%) of them had given cow/buffalo's milk and 22.6 percent had given honey. A meagre percentage of mothers had given tea, powdered milk, pulse water (Table 2).

There was no association between religion, caste and birth order with the practice of giving prelacteal feeding as it was not found statistically significant ( $p>0.05)$. Only mother's education ( $\mathrm{p}<0.01$ ), father's education ( $\mathrm{p}<$ $0.001)$ and socioeconomic status $(p<0.05)$ were statistically associated with the practice of giving prelectial feeding (Table 3).

\section{DISCUSSION}

In present study it was found that half (50.6\%) of the mothers had given prelacteal feed to their newborn.

In contrast to our study, Singh (2002) in a study in rural

Table 1. Socio-demographic characteristics of study population/respondents $(\mathrm{N}=524)$.

\begin{tabular}{|c|c|c|c|c|}
\hline \multicolumn{3}{|c|}{ Characteristics } & No. & Percent \\
\hline \multirow{5}{*}{$\begin{array}{l}\text { Religion and } \\
\text { caste }\end{array}$} & \multicolumn{2}{|c|}{ Muslim } & 154 & 29.4 \\
\hline & \multicolumn{2}{|c|}{ Hindu } & 370 & 70.6 \\
\hline & \multicolumn{2}{|c|}{ General } & 56 & 10.7 \\
\hline & \multicolumn{2}{|c|}{$\mathrm{OBC}$} & 176 & 33.6 \\
\hline & \multicolumn{2}{|c|}{$\mathrm{SC} / \mathrm{ST}$} & 138 & 26.3 \\
\hline \multirow{2}{*}{ Type of family } & \multicolumn{2}{|c|}{ Nuclear } & 367 & 70.0 \\
\hline & \multicolumn{2}{|c|}{ Joint } & 157 & 30.0 \\
\hline \multirow{5}{*}{$\begin{array}{c}\text { Socio-economic } \\
\text { status }\end{array}$} & \multicolumn{2}{|c|}{ I } & 0 & 0.0 \\
\hline & \multicolumn{2}{|c|}{ II } & 40 & 7.6 \\
\hline & \multicolumn{2}{|c|}{ III } & 35 & 6.7 \\
\hline & \multicolumn{2}{|c|}{ IV } & 66 & 12.6 \\
\hline & \multicolumn{2}{|c|}{$\mathrm{V}$} & 351 & 67.0 \\
\hline \multirow{3}{*}{ Family size } & \multicolumn{2}{|c|}{$<5$} & 195 & 37.2 \\
\hline & \multicolumn{2}{|c|}{$5-6$} & 192 & 36.6 \\
\hline & \multicolumn{2}{|c|}{$>6$} & 137 & 26.1 \\
\hline \multirow{2}{*}{ Education } & \multicolumn{2}{|c|}{ Mother } & \multicolumn{2}{|c|}{ Father } \\
\hline & No. & Percentage & No. & Percent \\
\hline Illiterate & 312 & 59.5 & 240 & 45.8 \\
\hline Up to primary & 63 & 12.0 & 58 & 11.1 \\
\hline $\begin{array}{l}\text { Junior/high } \\
\text { school }\end{array}$ & 111 & 21.2 & 146 & 27.8 \\
\hline Intermediate & 20 & 3.8 & 29 & 5.5 \\
\hline Graduate \& + & 18 & 3.4 & 51 & 9.7 \\
\hline
\end{tabular}


Table 2. Practices of pre-lacteal feeding (within one month of birth) $(\mathrm{N}=524)$.

\begin{tabular}{ccc}
\hline Practice & No. & Percent \\
\hline Not given & 259 & 49.4 \\
Given & 265 & 50.6 \\
Sugar water & 19 & 7.2 \\
Boiled water & 131 & 49.4 \\
Honey & 60 & 22.6 \\
Mugli ghutti/gripe water & 146 & 55.1 \\
Tea & 3 & 1.2 \\
Powdered milk & 18 & 6.8 \\
Dal water & 2 & 0.8 \\
Cow/Buffalo's milk & 92 & 34.7 \\
Others & - & - \\
\hline
\end{tabular}

${ }^{*}$ Multiple response.

area of Ghaziabad, UP reported that 96.4 percent of mothers gave prelacteal feed to their neonates, which is higher than in present study [7].

Koshore et al. (1999) in a study found that out of those who had given prelacteal (50.6\%), 55.1 percent of them given Mugli Ghuti and 49.4 percent gave boiled water as prelacteal feed [8].

In contrast to this study Singh et al. (2002) in their study found that gur or sugar water as prelacteals by majority (80\%) of mothers, only 2.7 percent had given Mugli Ghutti as prelacteal feed [7].

Similarly Kishore et al. (1999) in their study in rural area found that 49 percent of mothers gave sugar water as prelacteal feed [8].

Incontrast to our study Kalra et al. (1982) had reported the practice of prelacteal feeding in urban areas of Agra to be 85 percent and 95 percent in rural area of Agra which are higher than in this study [9].

Satapathy et al. (1984) reported this practice of prelacteal feeding by 73 percent mothers from South Orissa $[10,11]$ and Kumar et al. (1989) had reported that 90.9 percent mothers in Delhi had given prelacteal to their newborns, finding of both the study the higher than in the present study [12]. It was concluded that maternal knowledge and awareness of correct feeding practices is essential for the normal growth, health and well being of the children. We therefore suggested that the primary focus of various nutrition related national programs in India for children should aim at imparting nutrition and health education to the mothers.

Importance of Study finings: As the study shows that by educating the parents we can improve feeding practices in Newborns. More awareness is needed to improve
Table 3. Association between demographic characteristics and practice of giving pre-lacteal feeding.

\begin{tabular}{|c|c|c|c|c|c|}
\hline \multirow{2}{*}{\multicolumn{2}{|c|}{$\begin{array}{l}\text { Demographic } \\
\text { characteristics }\end{array}$}} & \multirow{2}{*}{ No. } & \multicolumn{2}{|c|}{$\begin{array}{l}\text { Pre-lacteal } \\
\text { feed }\end{array}$} & \multirow{2}{*}{$\begin{array}{c}\text { Test } \\
\text { statistics }\end{array}$} \\
\hline & & & No. & $\%$ & \\
\hline \multirow{2}{*}{ Religion } & Hindu & 370 & 193 & 52.2 & \multirow{2}{*}{$\begin{array}{c}\chi^{2}=1.27 \\
d f=1 \\
p>0.05\end{array}$} \\
\hline & Muslim & 154 & 72 & 46.8 & \\
\hline \multirow{3}{*}{ Caste } & General & 56 & 27 & 48.2 & \multirow{3}{*}{$\begin{array}{c}\chi^{2}=0.86 \\
\mathrm{df}=2 \\
\mathrm{p}>0.05\end{array}$} \\
\hline & OBC & 176 & 96 & 54.5 & \\
\hline & $\mathrm{SC} / \mathrm{ST}$ & 138 & 70 & 50.7 & \\
\hline \multirow{3}{*}{$\begin{array}{l}\text { Type of } \\
\text { family }\end{array}$} & Joint & 367 & 188 & 51.2 & \multirow{3}{*}{$\begin{array}{c}\chi^{2}=0.21 \\
\mathrm{df}=1 \\
\mathrm{p}>0.05\end{array}$} \\
\hline & Nuclear & 157 & 77 & 49.0 & \\
\hline & Illiterate & 312 & 160 & 51.3 & \\
\hline \multirow{4}{*}{$\begin{array}{c}\text { Education } \\
\text { of } \\
\text { mother }\end{array}$} & Up to primary & 63 & 41 & 65.1 & \multirow{4}{*}{$\begin{array}{c}\chi^{2}=15.15 \\
d f=4 \\
p<0.01^{*}\end{array}$} \\
\hline & $\begin{array}{l}\text { Junior/high } \\
\text { school }\end{array}$ & 111 & 54 & 48.6 & \\
\hline & Intermediate & 20 & 4 & 20.0 & \\
\hline & Graduate \& + & 18 & 6 & 33.3 & \\
\hline \multirow{5}{*}{$\begin{array}{l}\text { Education } \\
\text { of father }\end{array}$} & Illiterate & 240 & 115 & 47.9 & \multirow{5}{*}{$\begin{array}{c}\chi^{2}=7.73 \\
\mathrm{df}=4, \\
\mathrm{p}<0.001^{*}\end{array}$} \\
\hline & Up to primary & 58 & 38 & 65.5 & \\
\hline & $\begin{array}{l}\text { Junior/high } \\
\text { school }\end{array}$ & 146 & 77 & 52.7 & \\
\hline & Intermediate & 29 & 12 & 41.4 & \\
\hline & Graduate \& + & 51 & 23 & 45.1 & \\
\hline \multirow{3}{*}{$\begin{array}{l}\text { Birth } \\
\text { order }\end{array}$} & 1 & 150 & 76 & 50.7 & \multirow{3}{*}{$\begin{array}{c}\chi^{2}=3.83 \\
\mathrm{df}=2 \\
\mathrm{p}>0.05\end{array}$} \\
\hline & $2-3$ & 266 & 143 & 53.8 & \\
\hline & $4+$ & 108 & 46 & 42.6 & \\
\hline \multirow{4}{*}{ SES } & II & 40 & 25 & 62.5 & \multirow{4}{*}{$\begin{array}{c}\chi^{2}=9.92 \\
\mathrm{df}=3, \\
\mathrm{p}<0.05^{*}\end{array}$} \\
\hline & III & 35 & 22 & 62.9 & \\
\hline & IV & 66 & 24 & 36.4 & \\
\hline & V & 383 & 194 & 50.6 & \\
\hline
\end{tabular}

*Significant.

correct feeding practices.

\section{CONCLUSION}

It was concluded that maternal knowledge and awareness of correct feeding practices is essential for the normal growth, health and well being of the children. We therefore suggested that the primary focus of various nutrition related national programs in India for children should aim at imparting nutrition and health education to the mothers. It is recommended that policy makers should look into the issue to give more emphasis in the promotion of EBF through empowerment of omen and 
other corrective measures to the achievement of the fourth millennium development goal.

\section{REFERENCES}

[1] Akra, J. (1989) Infant feeding: The physiological basis. Bulletin of the World Health Organization, 67, 101-108.

[2] Ghosh, S. and Shah, D. (2004) Nutritional problems in urban slums. Indian Pediatrics, 41, 682-696.

[3] Peters, E., Wehkamp, K.-H., Felberbaum, R.E., Ger, D.K. and Linder, R. (2005) Breastfeeding duration is determined by only a few factors. European Journal of Public Health, 16, 162-167. doi:10.1093/eurpub/cki199

[4] Foo, L.L., Quek, S.J.S., Ng, S.A., Lim, M.T. and Deurenbergyap, M. (2005) Breastfeeding prevalence and practices among Singaporean Chinese, Malay and Indian mothers. Health Promotion International, 20, 229-237. doi:10.1093/heapro/dai002

[5] Federal Ministry of Health (2005) National strategy for child survival in Ethiopia. Federal Ministry of Health, Addis Ababa.

[6] Jones, G., Steketee, R.W., Black, R.E., Bhutta, Z.A. and
Morris, S.S. (2003) How many child deaths can we prevent this year? The Lancet, 362, 65-71. doi:10.1016/S0140-6736(03)13811-1

[7] Singh, D. (2002) A study of the knowledge, attitude and practices regarding care of the neonate in rural community. Faculty of Medical Sciences, University of Delhi, Delhi.

[8] Kishore, S. and Garg, B.S. (1999) Practice of prelacteal feeding in rural community. Indian Journal of Public Health, 43, 144-147.

[9] Kalra, K. and Dayal, R.S. (1982) Breast-feeding practices in different residential economic and education groups. Indian Pediatrics, 19, 5-11.

[10] Satapathy, R.K., Saranji, K.S. and Das, D.K.A. (1984) Community survey on infant feeding practices in Behrampur South Orissa. Indian Pediatrics, 21, 207-213.

[11] Singh, D., Varughese, P.V. and Singh, S. (1992) Outcome of hospitalized out-born pre-term babies. Indian Journal of Maternal \& Child Health, 3, 104-107.

[12] Kumar, S. and Nath, I.M. (1989) Breast feeding practices in resettlement colony and its implication for promotional activities. Indian Journal of Pediatrics, 56, 239-241. doi:10.1007/BF02726617 